\title{
Benjamin Tromly Making the Soviet Intelligentsia: Universities and Intellectual Life under Stalin and Khrushchev
}

Cambridge, UK: Cambridge University Press, 2014. xiv, 295 pp.

\section{J.-Guy Lalande}

St. Francis Xavier University

The founders of the Soviet state did not conceive of the university as an institution devoted, first and foremost, to the pursuit of impartial learning; au contraire, they believed that learning was valuable only insofar as it helped build the Communist future. Such a premise explains the highly regimented environment of the universities in the USSR - a situation, though, that did not imply their relative irrelevance. Indeed, higher learning was much prized — and with good reason. Since the state had a near monopoly on employment, a higher education diploma meant an escape from manual labour, a ticket to a professional career, and, given the state's close control over population movements, a precious path for geographical mobility from villages and small towns to the more comfortable cities. Furthermore, in the wake of the Second World War, both sides of the Iron Curtain, anxious to harness the potential of universities for economic development and national defence, sponsored the development of more institutions of higher learning.

This absorbing book, which began as a doctoral dissertation at Harvard University, is about the occupants of these institutions: the professors and students who made up the so-called Soviet intelligentsia. The author first acknowledges that the word intelligentsia is coloured by methodological presumptions and ideological affinities, then defines it as a creation of the Stalin era as well as a status group. Its members, once they had received a quality education, were compelled to become - whether as engineers, scientists, bureaucrats, doctors, or teachers - agents of enlightenment and civilization in their own respective milieux. The regime expected that Soviet higher learning would produce a Soviet intelligentsia that would be "as politically docile as it was technically competent" (120). To what extent was this highly ambitious objective achieved? Tromly answers this question in a finely nuanced way. While conceding 
that loyalty to the cause (partiinost') did express itself, he also provides multiple examples of initiatives sponsored by faculty and students that ran afoul of party authorities - such as the youth opposition groups that penned revolutionary programs; student hostility to Stalin's anti-Semitic campaigns; the holding of independent poetry readings; the resistance to the onslaught of Lysenkoism in higher education; the failure of Nikita S. Khrushchev's attempts to, first, transform the universities through an overhaul of admissions that would favour toilers and ex-servicemen at the expense of the sons and daughters of members of the intelligentsia, and second, to introduce into the curriculum a physical labour component to close the gap between the world of work and the life of the mind; and finally, the rise of politicized national identities in Ukraine and Russia and (conversely) the rejection of Soviet models of nationhood.

Tromly focused his research on three institutions: T. H. Shevchenko Kyiv State University, M. V. Lomonosov Moscow State University, and N. G. Chernyshevskii Saratov State University. Though they were diverse in terms of size, urban environment, material resources, academic reputation, and contacts with the outside world, these universities shared one fundamental characteristic - they constituted spaces where professors and students could locate and construct different ideas about the Soviet intelligentsia. Indeed, the originality of this book resides in its presentation of the Soviet intelligentsia as "an historically constructed set of identifications and ideas ... rather than a collectivity with clear borders that acted with one will” (12). The author draws upon a wide array of sources - the records of party and state bureaucracies, university administrations, labour and Komsomol (All-Union Leninist Young Communist League) organizations, reports from exchange students visiting the Soviet Union and defectors from it, memoirs, and forty-nine interviews. The latter are a personal source that helps contextualize an always incomplete archival base; but they should be used carefully, since memory has a tendency to erode and restructure experiences.

This remarkable study also presents an undeniable interest from a historiographical point of view. There should be a large consensus that a detailed study of university life offers a perspective from which to reconsider major issues in post-war Soviet history. By showing how party policies collided with entrenched university communities, whose cherished elitism was very much part of their social identity, Tromly provides yet another example that undermines the concept of totalitarianism as the defining feature of the Soviet regime. Not all readers, though, will agree with his emphasis on the continuity between Stalinism and post-Stalinism. To argue, as he does, that Soviet authorities both before and after Stalin's death in March 1953 faced the same dilemma of maintaining a sense of revolutionary momentum in Soviet society while they were still simultaneously wrestling with the consequences of a particularly devastating war, and the geopolitical context of the Cold War, should not entitle one to minimize the obvious elements of rupture between the so-called Stalinist Winter and Khrushchevian Thaw. Such an approach, which Tromly takes, not only fails to establish a clear distinction between the objectives envisioned by both Soviet leaders and the means used to achieve them, but also reveals an inadequate- possibly flawed - understanding of the Khrushchev years in particular. 
Making the Soviet Intelligentsia, a book that explores relationships among society, learning, and identity in the Soviet Union between 1945 and 1964, is exceptionally well researched; on the other hand, it is very far from being an easy read. Readers not familiar with the cultural turn that quite a few historians have recently embraced will struggle mightily in trying to make sense of Tromly's complex prose and arguments. Nevertheless, the image Tromly presents of a student body attempting to bring about the moral regeneration of society through culture is refreshing; he deserves much praise for having painted it with such a rich palette. 